\title{
Managing Turfgrasses during Drought
}

M. ALI HARIVANDI, University of California Cooperative Extension Advisor, San Francisco Bay Area; JAMES BAIRD, Turfgrass Specialist, University of California, Riverside; JANET HARTIN, University of California Cooperative Extension Advisor, San Bernardino County; MICHAEL HENRY, University of California Cooperative Extension Advisor, Riverside County; DAVID SHAW, University of California Cooperative Extension Advisor, San Diego County

\section{INTRODUCTION}

Most of California has a Mediterranean climate characterized by long, hot, dry summers, and turfgrasses must be watered to survive under these conditions. Californians must learn how to use water more efficiently as demand and cost rise and drought conditions continue.

Warm-season and cool-season grasses are used as turfgrass in California, based on their climatic adaptability. The warm-season species include common and hybrid bermudagrasses, St. Augustinegrass, seashore paspalum, zoysiagrass, buffalograss, and kikuyugrass. These grasses are used in the San Joaquin Valley, southern California, and parts of the greater San Francisco Bay Area. The cool-season grasses include tall fescue, perennial ryegrass, Kentucky bluegrass, fineleaf fescues in mixes, and specialty grasses such as creeping bentgrass and rough bluegrass. Turfgrasses can be irrigated at different levels. The Optimum irrigation is the amount of water needed for the most efficient growth, maximum quality, and best appearance of the respective turfgrasses. Deficit irrigation provides sufficient water to maintain adequate turfgrass appearance with less growth. In contrast, survival irrigation provides only enough water to allow survival and potential recovery of the desired species when adequate water is again available. Under survival irrigation, growth and quality are drastically reduced.

Figure 1 presents the percentage of reference evapotranspiration (ETo) obtained from the California Irrigation Management Information System, relative to the three irrigation levels for warmand cool-season turfgrasses. Figure 1 also

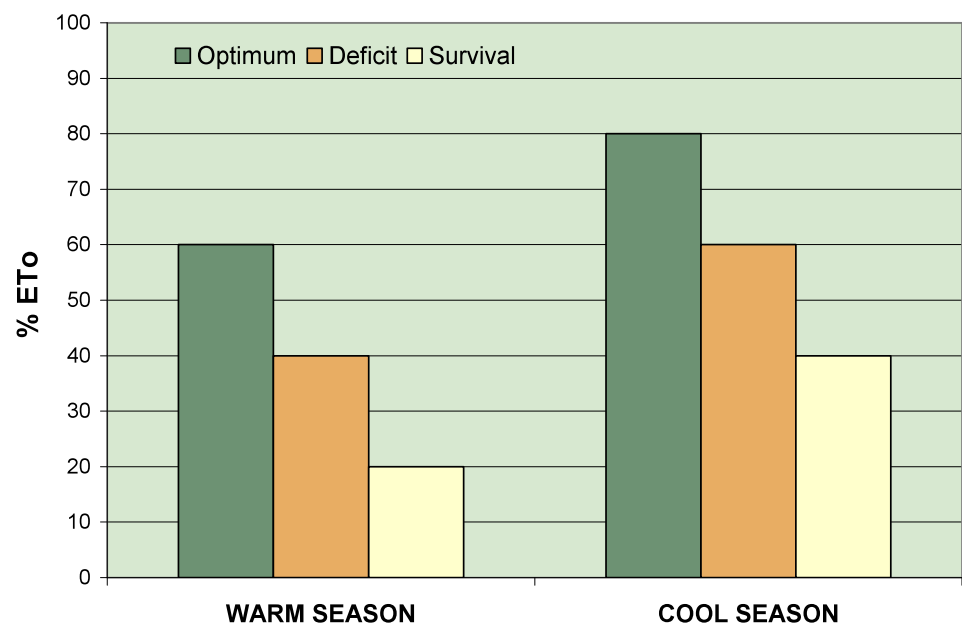

Figure 1. Turfgrass water requirements (as \% of ETo) at optimum, deficit, and survival levels of irrigation. 
indicates that both cool-season and warm-season turfgrasses, when irrigated at deficit levels, can save at least 25 percent of irrigation water needed for optimum growth. Irrigation at a survival rate would be at 30 percent of optimum for warm-season turfgrasses and about 50 percent of optimum for cool-season turfgrasses.

If water rationing is needed, both cool-season and warm-season turfgrasses can be irrigated at less than optimum levels. Where possible, using warmseason turfgrasses can result in considerable water savings compared with cool-season turfgrasses.

\section{BACKGROUND}

Turfgrass directly affects the way most Californians live. It provides the play medium on many recreational facilities, cools the immediate environment, reduces reradiated heat, and provides an aesthetically pleasing and functional home landscape. In addition, the turfgrass industry has a significant direct economic impact on our economy and indirect impact on our tourist economy.

Many recreational facilities depend on uniform, vigorously growing, well-maintained turf that is able to recuperate from heavy use. These include soccer, baseball, and football fields, as well as golf courses, bowling greens, lacrosse and polo fields, general use and specialty parks, and school playgrounds. Turfgrasses provide a safety cushion that is especially beneficial in contact and physically intensive sports. Additionally, sites such as homes, industrial parks, cemeteries, greenbelts, roadsides, and dog parks can benefit from low-growing and traffic-tolerant green vegetation like turfgrasses.

Most Californians now live in urban and suburban centers where glass, steel, concrete, asphalt, buildings, and cars prevail; turfgrasses directly influence these immediate environments in positive ways. Actively growing turfgrasses reduce high summer ground surface temperatures due to transpirational cooling. Turfgrasses and other landscape plants reduce discomforting glare and noise. Soil erosion, dust, and fire danger are reduced or eliminated on turfed surfaces. Turfgrasses also increase infiltration of water into the soil profile and also enhance the quality of the water moving through or below the turfgrass system.

\section{How TURfGRAsses USE Water}

Water enters a turfgrass plant through its root hairs, which are located near root tips. Water then moves upward through the plant to the leaves. A very small amount of the water taken up is used for plant growth, and the rest of the water transpires out of the plant through the stomatal pores. Water can also be lost from the turfgrass site by evaporation from leaf or soil surfaces. The water use rate is the total amount of water lost by a plant through evaporation and transpiration and used for growth, per unit of time. Because the amount of water used by turfgrasses for growth is so small, the water use rate is usually calculated as the evapotranspiration (ET) rate, which is the total rate of water loss by evaporation plus the rate of water loss by transpiration.

ET is expressed in units of depth and time such as inches (in) or millimeters (mm) per day, per week, or per month. Turfgrass ET depends on temperature, solar radiation, day length, wind, relative humidity, and other environmental factors. However, the ET rate also varies by species and the cultural practices used in maintaining the turf.

Water use rates have been established for the most commonly used warm- and cool-season turfgrass species. Research at Texas A\&M in the late 1980 s evaluated comparative water use rates among turfgrasses commonly grown in the United States. The comparative water use rates for those grasses used in California are presented in table 1. In the northern part of California and in the mountain regions of the state, turfgrasses are exclusively cool-

Table 1. Evapotranspiration rates of turfgrasses commonly grown in California

\begin{tabular}{|l|l|l|l|}
\hline $\begin{array}{l}\text { Relative } \\
\text { ranking }\end{array}$ & $\begin{array}{l}\text { ET rate } \\
\text { (in./day) }\end{array}$ & $\begin{array}{l}\text { Cool-season } \\
\text { turfgrasses }\end{array}$ & $\begin{array}{l}\text { Warm- } \\
\text { season } \\
\text { turfgrasses }\end{array}$ \\
\hline very low & $<0.24$ & buffalograss \\
\hline low & $0.24-0.28$ & $\begin{array}{l}\text { bermudagrass } \\
\text { zoysiagrass }\end{array}$ \\
\hline medium & $0.28-0.33$ & $\begin{array}{l}\text { hard fescue } \\
\text { Chewing's fescue } \\
\text { red fescue } \\
\text { seashore paspalum } \\
\text { St. Augustine grass }\end{array}$ \\
\hline high & $0.33-0.39$ & $\begin{array}{l}\text { perennial ryegrass } \\
\text { kikuyugrass }\end{array}$ & \\
\hline very high & $>0.39$ & $\begin{array}{l}\text { tall fescue } \\
\text { creeping bentgrass } \\
\text { annual bluegrass } \\
\text { Kentucky } \\
\text { bluegrass } \\
\text { rough bluegrass } \\
\text { annual ryegrass }\end{array}$ \\
\hline
\end{tabular}

Note: 1 inch $=2.54 \mathrm{~cm}$.

Source: Adapted from Beard and Beard 2004. 
Table 2. Suggested Kc values (\% of ETo) for irrigation strategies resulting in optimum, deficit, and survival performance levels for selected turfgrasses grown in California.

\begin{tabular}{l|c|c|}
\multirow{2}{*}{ Turfgrass performance level } & Cool-season turfgrasses & Warm-season turfgrasses \\
\cline { 2 - 3 } & $\mathrm{Kc}^{*}$ & $\mathrm{Kc}$ \\
\hline optimum & 0.80 & 0.60 \\
\hline deficit & 0.60 & 0.40 \\
\hline survival & 0.40 & 0.20
\end{tabular}

Note: * Kc (crop coefficient) is a dimensionless number that is multiplied by the ETo value to arrive at an estimate of crop ET, or water requirement.

season species. In other areas of the state, warmseason turfgrasses are grown extensively, and they perform well particularly in warm inland climates and desert areas. Both cool-season and warmseason species are grown in major populated areas of the state. Differences in water use rates have been noted between cultivars within all turfgrass species. Currently, research is underway throughout the United States to develop species and cultivars that have low water use rates. The lower-water-use turfgrasses have a low leaf-blade area and include species with narrow leaves with slow vertical extension rates and grasses with high shoot densities and high leaf numbers.

Warm-season turfgrass species use significantly less water than cool-season species. This is because warm-season grasses are more efficient at photosynthesis and are able to continue high-level carbohydrate production even under mild water stress when their stomates are partially closed. By contrast, cool-season grasses use a less efficient photosynthetic process and cannot produce enough carbohydrate to maintain growth unless their stomates are nearly wide open. Thus, when water is limited, transpiration rates of cool-season turfgrasses are generally higher than those of warm-season turfgrasses.

The effects of irrigating several species of turfgrasses below their optimal levels were investigated at Irvine, California. Cool-season grasses tested were Kentucky bluegrass, perennial ryegrass, and tall fescue; warm-season turfgrasses were hybrid bermudagrass, zoysiagrass, and seashore paspalum. Irrigation regimes supplied 100,80 , or 60 percent of calculated ET for each species. For acceptable turfgrass quality, 36 percent less water was required by the warm-season species than by the cool-season species.

Similar irrigation regimes can be created for any area of the state using ETo information and the crop coefficient $(\mathrm{Kc})$ values (expressed as a percentage of ETo needed to satisfy water needs of a specific plant species) in table 2 .

\section{Water Use Versus Drought Resistance}

The ET of a turfgrass is not synonymous with its ability to resist drought. Drought resistance includes mechanisms of drought avoidance (i.e., of retaining moisture within the plant) and of drought tolerance (i.e., of minimizing the damage to tissues caused by water deprivation).

Plant characteristics that contribute to drought avoidance include deep root systems with high root hair length and density, rolled leaf blades, thick cuticle (or ability to quickly form a thick cuticle following water stress initiation), reduced leaf area, slow leaf extension rates, and leaf orientation and density. Examples of turfgrasses with good drought avoidance mechanisms are common bermudagrass and seashore paspalum (both warm-season species) and tall fescue (a cool-season species).

Turfgrasses can also tolerate drought by escape (e.g., buffalograss, which tolerates drought with a dormancy mechanism) or by high tolerance to tissue dehydration (e.g., St. Augustinegrass). Through these mechanisms, turfgrass species have different levels of drought resistance (table 3). Comparison of the water use rates (table 1) and drought resistance (table 3) gives insight into the performance turfgrass species. Several turfgrasses, such as bermudagrass, seashore paspalum, and buffalograss, have both low water use rates and high drought resistance mechanisms. Other turfgrasses, such as tall fescue, have high water use rates and medium drought resistance. Still others, such as the ryegrasses and bluegrasses, have high water use rates and fair or poor drought resistance.

Some turfgrasses and ground covers can survive with very little applied water, as evidenced by a research study conducted at the South Coast 
Table 3. Drought resistance comparisons of turfgrasses commonly grown in California.

\begin{tabular}{|c|c|c|}
\hline $\begin{array}{l}\text { Relative } \\
\text { ranking }\end{array}$ & $\begin{array}{l}\text { Cool-season } \\
\text { turfgrasses }\end{array}$ & $\begin{array}{l}\text { Warm-season } \\
\text { turfgrasses }\end{array}$ \\
\hline superior & - & $\begin{array}{l}\text { bermudagrass (common) } \\
\text { bermudagrass (hybrid) } \\
\text { buffalograss }\end{array}$ \\
\hline excellent & - & $\begin{array}{l}\text { seashore paspalum } \\
\text { zoysiagrass }\end{array}$ \\
\hline good & - & $\begin{array}{l}\text { St. Augustinegrass } \\
\text { kikuyugrass }\end{array}$ \\
\hline medium & tall fescue & - \\
\hline fair & $\begin{array}{l}\text { perennial ryegrass } \\
\text { Kentucky bluegrass } \\
\text { creeping bentgrass } \\
\text { hard fescue } \\
\text { Chewing's fescue } \\
\text { red fescue }\end{array}$ & - \\
\hline poor & $\begin{array}{l}\text { colonial bentgrass } \\
\text { annual bluegrass }\end{array}$ & - \\
\hline very poor & rough bluegrass & - \\
\hline
\end{tabular}

Field Station, Irvine, California, in which plants were irrigated at 60, 40, and 20 percent of calculated ET. Of the 27 plant species tested, common and hybrid bermudagrasses and seashore paspalum performed best under very low irrigation regimes. Buffalograss also produced comparatively good cover and quality.

\section{IrRigation AND Other CULtural Practices for TURfGRASS}

\section{Irrigation}

The goal of irrigation management is to apply the correct amount of water at the correct time to optimize water uptake by the root system. It is also important to reduce the amount of water lost to runoff from the soil surface and deep percolation below the root zone. Regular water audits, ensuring that equipment is operating correctly, and using soil probes or soil moisture measuring devices help finetune irrigation schedules, promote healthy turfgrass, and decrease water waste.

Effective irrigation involves filling the root zone soil profile with each irrigation. This requires calculating the amount and frequency of water application based on weather data (used to estimate the ET of the turfgrass), the plant's rooting depth, and the water-holding capacity of the soil. These factors may also be used to plan deficit irrigation strategies.

\section{Evapotranspiration and CIMIS}

The California Irrigation Management System (CIMIS) provides irrigation managers, scientists, and water agencies with an accurate, site-specific means of estimating plant water demand based on the climatic parameters that drive evapotranspiration in plants. Reference evapotranspiration (ETo) approximates the water use of an irrigated grass pasture. Water use (ET) by turfgrasses is estimated by means of a correlation factor, the crop coefficient (Kc), according to the formula

$$
\mathrm{ET}=\mathrm{ETo} \times \mathrm{Kc}
$$

Turfgrass Kc values fluctuate slightly during the season based on the percentage of plant cover, growth rate, root growth, stage of plant development, and turf management practices. For practical purposes, the Kc of cool-season turfgrasses is 0.8 , and the $\mathrm{Kc}$ for warm-season turfgrasses is 0.6. Numerous CIMIS stations are located in varying climatic zones throughout California; daily water use information (i.e., ETo) is accessible online for most areas of California at the CIMIS website, http://www.cimis.water.ca.gov/cimis/welcome.jsp.

\section{Soil water availability}

The amount of water available for use by turfgrasses varies by soil texture and pore size and by the rooting depth of the turfgrass. After soil is irrigated and free drainage has taken place, the soil is full of water, or at field capacity. As plants extract the water from the soil, eventually the soil will become so dry that plants cannot be sustained. At this point (often called the permanent wilting point or percentage) there is still water in the soil but it is tightly held by mineral and organic particles and is unavailable for plant use. The total amount of water a soil can hold and the amount of available water a plant can absorb and use differ with different soil textures (table 4). These data, in conjunction with root depth, give the approximate amount of water that is available to a turfgrass plant.

\section{Root system}

Turfgrass species differ in their rooting depth and density Rooting depths vary from a few inches to many feet; they are also influenced by water patterns, soil characteristics, management practices such as mowing and fertilization, and by on-site compaction. The best method to determine root depth in a particular location is by digging into the 
Table 4. Unavailable and available water for selected soil textures.

\begin{tabular}{|c|c|c|c|}
\hline Soil texture & $\begin{array}{l}\text { Total water } \\
\text { (in/ft) }\end{array}$ & Available water (in/ft) & $\begin{array}{l}\text { Unavailable water } \\
\text { (in/ft) }\end{array}$ \\
\hline sand & $0.6-1.8$ & $0.4-1.0$ & $0.2-0.8$ \\
\hline sandy loam & $1.8-2.7$ & $0.9-1.3$ & $0.9-1.4$ \\
\hline loam & $2.7-4.0$ & $1.3-2.0$ & $1.4-2.0$ \\
\hline silt loam & $4.0-4.5$ & $2.0-2.1$ & $2.0-2.4$ \\
\hline clay loam & $4.2-4.8$ & $1.8-2.1$ & $2.4-2.7$ \\
\hline clay & $4.5-4.8$ & $1.8-1.9$ & $2.7-2.9$ \\
\hline
\end{tabular}

Note: $1 \mathrm{in} / \mathrm{ft}=8.3 \mathrm{~cm} / \mathrm{m}$

soil and looking at the roots. Table 5 is a general guide to root depths. The available soil water is determined by multiplying the available water by the effective depth of the root system. Table 6 shows the amount of water available to turfgrasses growing in various soils at selected root system depths. Since proper irrigation should supply water to the root system, root depths and soil texture play an important role in both the amount of water applied and irrigation frequency.

Table 5. Approximate root depths of common California turfgrasses under normal use conditions.

\begin{tabular}{l|l|}
\hline Cool-season grasses & Root depth (ft) \\
\hline Kentucky bluegrass & $0.5-1.5$ \\
\hline perennial ryegrass & $0.5-1.5$ \\
\hline tall fescue & $1.5-3.0$ \\
\hline creeping bentgrass & $0.3-1.5$ \\
\hline annual bluegrass & $0.1-0.3$ \\
\hline Warm-season grasses & \\
\hline bermudagrass & Root depth (ft) \\
\hline buffalograss & $1.5-6.0$ \\
\hline St. Augustinegrass & $1.5-3.0$ \\
\hline seashore paspalum & $1.5-5.0$ \\
\hline zoysiagrass & $1.5-5.0$ \\
\hline
\end{tabular}

Note: $1 \mathrm{ft}=0.348 \mathrm{~m}$.

\section{Irrigation frequency}

For scheduling turfgrass irrigation, the suggested depletion of available soil water is 50 percent before applying irrigation. In other words, irrigation is needed when one-half the available water that is present in a root profile is depleted. This practice allows for adequate water to be available at all times. If more than 50 percent of the available water is depleted (i.e., irrigations are not frequent enough), the turf suffers water stress.

Fifty percent of the available water divided by the ET equals the number of days of sufficient supply, or the number of days between irrigations. For example, for a cool-season turfgrass $(\mathrm{Kc}=0.8)$ with a 12-inch rooting depth in a loam soil, the available water is 1.5 inches (from table 6). Fifty percent of 1.5 is 0.75 inches. If the ETo is 0.2 inches per day, the turfgrass ET equals $0.20 \times 0.8$, or 0.16 inches per day $(\mathrm{ETo} \times \mathrm{Kc})$. It will take about 5 days $(0.75 \div 0.16=4.7)$ to deplete 50 percent of the available water. It is normally desirable to water turf as infrequently as possible, so in this case the site would be irrigated by applying 0.80 inches $(0.16 \times 5)$ of water after 5 days.

\section{Water application}

The duration of sprinkler operation to resupply the water used by ET must be determined on-site and depends on how fast and how efficiently the water

Table 6. Water available to turfgrass under three soil textures and with three root system depths.

\begin{tabular}{l|c|c|c|c|}
\hline \multirow{2}{*}{ Soil texture } & \multicolumn{2}{|c|}{$\begin{array}{c}\text { Available water } \\
\text { (in/ft) }\end{array}$} & \multicolumn{3}{|c|}{ Water available (in/ft) to turfgrass at root depth } \\
\cline { 2 - 5 } & 1.0 & 6 in. & 12 in. & 36 in. \\
\hline sand & 1.5 & 0.5 & 1.0 & 3.0 \\
\hline loam & 2.0 & 1.0 & 2.0 & 4.5 \\
\hline clay loam & & 1.0 & 6.0 \\
\hline
\end{tabular}

Note: $1 \mathrm{in} / \mathrm{ft}=8.3 \mathrm{~cm} / \mathrm{m}$ 
is applied. The efficiency of irrigation is a function of system performance and management. Irrigation systems that are well designed, in good condition, and apply water uniformly will be much easier for managers to schedule.

The fieldwork to determine system performance can be either a brief, simple procedure or a complete, full inspection of all the irrigation system stations and hardware. Often referred to as an irrigation audit, the process is used to accurately determine the system precipitation rate $(\mathrm{PR})$ and distribution uniformity (DU).

The precipitation rate is the rate at which water is delivered to the turfgrass area; it is measured in inches per hour. The distribution uniformity is a calculated statistic that indicates the amount of variation in the precipitation rate of the system. The precipitation rate and the distribution uniformity are the two most important irrigation system performance characteristics in calculating station run times and determining how evenly water is applied to the area.

Irrigation uniformity is important in turfgrass areas, since turfgrass consists of many small plants, each requiring access to soil and water. An irrigation system with poor uniformity yields areas that are too wet or too dry and nonuniform turfgrass performance. If there are dry areas, irrigation managers usually increase runtime to adequately irrigate them. In this case, water loss to deep percolation or runoff can be significant and may increase with poorer distribution uniformity. The distribution uniformity is only one measure of system performance; information on other statistical measures, such as the Christiansen's coefficient of uniformity and the scheduling coefficient, as well as procedures for determining precipitation rates can be found in Evaluating Turfgrass Sprinkler Irrigation Systems (ANR Publication 21503).

The actual run time is determined by dividing the crop coefficient ( 0.80 inches of water used, in the above example) by the precipitation rate of the sprinkler system. The run time is increased if the irrigation efficiency is considered. The distribution uniformity is a good estimate of the irrigation efficiency as long as the scheduling (management) is good and runoff is limited.

Using the efficiency in the above example, the run time (in hours) would be calculated by dividing 0.80 inches by the precipitation rate times the distribution uniformity; multiply by 60 to convert to minutes. More detailed information on irrigation scheduling can be found in Turfgrass Irrigation Scheduling (ANR Publication 21499).

Every effort should be made to prevent runoff. Application of water in short cycles, until the entire amount of water has been applied, is an effective way to reduce water waste due to runoff.

To prevent puddling or runoff on clay or compacted soils, and to prevent excessive drainage in sandy soils, plan on irrigating turfgrasses no less frequently than every third day. The total amount of water to be applied stays the same, but it should be adjusted for more frequent applications. In the example shown above, instead of applying 0.8 inches of water every 5 days, apply 0.5 inches every third day. If too much water is applied at once, water is lost to runoff or percolation below the root zone.

\section{Deficit irrigation strategies}

In drought conditions, it may be advisable to reduce turfgrass irrigation to the deficit level or even to the survival level (see fig. 1). If that is the case, in the example given above, instead of using a crop coefficient of 0.8 , use the other reduced values given in table 2 . This strategy applies less water than the turfgrass has used, which results in mild water stress. The available water will gradually become depleted below 50 percent. As mentioned previously, turfgrass species with drought resistance (especially warm-season grasses) reduce their water use rate as available soil water is used up. To maintain adequate turf quality, careful irrigation management is necessary and cultural practices may need to be adjusted.

\section{Mowing}

In addition to irrigation practices, mowing affects turfgrass growth, including root system development and water use. Higher cutting heights promote deeper root systems and higher water use rates. The higher water use rate with taller turf results from the more open canopy and reduced shoot density. Conversely, closely mowed turf has higher shoot density and a tight canopy, characteristics which reduce evapotranspiration.

The frequency of mowing also affects evapotranspiration. The long grass leaves of infrequently mowed turfgrass use more water. Infrequently mowed turf is also aesthetically 
and functionally inferior to turfgrass maintained consistently at an appropriate height.

The desired balance is achieved by mowing practices that enhance root system depth and density (and thus drought resistance) while efficiently using water.

Combining all factors involved, the turfgrass should be maintained at the tallest allowable height, within the recommended mowing height range, for the species being grown. Turf mowed at the tallest allowable height for the individual species and at a frequency that allows no more than one-third of the leaf blade to be removed best achieves that balance. Table 7 recommends mowing height ranges for selected turfgrasses.

Mowing turfgrasses when it is hot or when the soil is dry can injure the plants. When grasses are stressed by heat and drought, such as during a drought-declared summer, it is best to mow infrequently at a taller height.

\section{Fertilization}

Sufficient amounts of most nutrients required for turfgrass growth are normally available in native soils. However, all turfgrasses require nitrogen

Table 7. Mowing height ranges for commonly grown turfgrasses.

\begin{tabular}{l|c|}
\hline Turfgrass species & $\begin{array}{c}\text { Cutting height range } \\
\text { (in.) }\end{array}$ \\
\hline Cool-season turfgrasses & \\
\hline creeping bentgrass & $0.2-0.5$ \\
\hline colonial bentgrass & $0.5-1.0$ \\
\hline red fescue & $1.0-2.0$ \\
\hline Kentucky bluegrass & $1.5-2.5$ \\
\hline perennial ryegrass & $1.5-2.5$ \\
\hline tall fescue & $1.5-3.0$ \\
\hline
\end{tabular}

Warm-season turfgrasses

\begin{tabular}{|l|c|}
\hline bermudagrass & $0.5-1.0$ \\
\hline zoysiagrass & $0.5-1.0$ \\
\hline seashore paspalum & $0.5-1.0$ \\
\hline St. Augustinegrass & $0.5-1.5$ \\
\hline kikuyugrass & $0.5-1.0$ \\
\hline
\end{tabular}

Note: 1 in $=2.54 \mathrm{~cm}$. fertilizer, and in some soils they need phosphorus, potassium /or iron and other essential elements.

Turfgrass fertilization practices directly influence water use: fertilization, especially nitrogen fertilization, increases turfgrass growth, and the greater the growth rate, the greater the water use. Root and shoot growth increase as nitrogen nutrition is raised from a deficiency level. The resulting deeper roots and more vigorous topgrowth benefit the turfgrass. Excessive nitrogen fertilization is not beneficial and can result in excessive topgrowth, poor root growth, and water pollution. To avoid excessive water use, nitrogen fertilizer programs must be monitored to produce the least amount of topgrowth and the greatest rooting possible within the use parameters of the turf. During drought, it is advisable that the lowest amount of nitrogen be applied within the recommended range. Most cool-season grasses grown as general purpose turf require about 2 pounds of actual nitrogen per 1,000 square feet (about 1 kilogram per 100 square meters), applied during March through April and again during late September through mid-October. During this period, due to temperature and water availability, grasses can use nitrogen efficiently to develop deep and extensive root systems. Fertilizing based on these recommendations allows the grass to survive deficit irrigation, heat, and drought stresses much better. Avoid nitrogen fertilization of cool-season grasses from May through September. During this period, if nitrogen must be applied because of play or other special use it should be applied lightly and infrequently. During drought, nitrogen application to warm-season grasses should not exceed 0.25 pounds of nitrogen per 1,000 square feet per month (125 grams per 1,00 square meters), between April and September.

Adequate potassium may increase the drought tolerance of turfgrass. In general, an application of 1 to 2 pounds of potassium $\left(\right.$ as $\mathrm{K}_{2} \mathrm{O}$ ) per 1,000 square feet ( 0.5 to 1 kilogram per 100 square meter) in spring (March through April) may provide increased drought tolerance during the summer months.

\section{Soil Compaction and Thatch}

Soil compaction reduces the root and shoot growth of turfgrasses and also lowers the water infiltration rates. Turfgrass quality decreases in compacted soils; water use decreases with the slower growing, poorer quality turfgrass cover. Soil aerification is recommended to improve aeration, which increases 
shoot and root growth, water infiltration rate, and water use efficiency.

Thatch is an intermingled layer of dead and living organic matter that develops between the soil surface and the green turfgrass tissue. It consists of roots, stems, stolons, and rhizomes. A deep thatch layer, if hydrophobic (water repellent), reduces or eliminates water infiltration into the turfgrass soil profile. Water use efficiency increases when thatch is maintained at acceptable depths (around one-half inch, or $13 \mathrm{~mm}$ ) and is not allowed to dry out.

Aerification and dethatching should be undertaken in fall (October) or spring (March or April) for optimum results. Avoid aerifying and dethatching in midsummer when high temperatures may negatively affect the grass.

\section{Other Considerations}

- Conduct an irrigation system uniformity test (audit) in spring to identify and correct the irrigation system's inefficiency and non-uniformity (see Evaluating Turfgrass Sprinkler Irrigation Systems, UCCE Publication 21503).

- Irrigate late at night or early in the morning. At these times water loss by evaporation is minimal and distribution uniformity is usually good because of good water pressure and limited wind.

- Avoid runoff by ensuring that water application rates are not greater than soil infiltration rates (the rate water enters the soil). To avoid runoff, cycle water applications by applying the required amount of water over a series of consecutive shorter irrigations. Cycling should not be confused with watering every day, which is not recommended.

- Apply less water in shaded areas than in areas of open sun. Soil moisture measuring devices can be used to determine water needs of turfgrasses growing in various microclimates. In general, during the hot summer months, grasses planted in shade require about half as much water as same grass grown nearby in full sun.

- Repair and maintain irrigation systems. Observe system operation and make necessary repairs to increase uniformity and climate runoff.
- Act now if your facility is considering installing a new, more effective and more efficient irrigation system.

- Regrade mounds and redesign topographic features that create irrigation challenges. Turfgrass grown on slopes and mounds is prone to water loss due to runoff. Landscape design features that deflect irrigation water intended for turfgrass to elsewhere, such as sidewalks, driveways, and other hard surfaces should be modified.

- Investigate irrigating with recycled water. Drought will happen again!

\section{ACKNOWLEDGMENT}

The authors wish to acknowledge Victor A Gibeault and Jewell Meyer, both UC Cooperative Extension, Riverside, Emeritus Specialists, and Stephen Cockerham, Superintendent of Agricultural Operations, UC Riverside, for their significant research work and input in developing the first edition of this publication in 1991. Without their years of research much of the information presented here would not have been available.

\section{REFERENCES}

Beard, J. B., and H. J. Beard. 2004. Beard's turfgrass encyclopedia for golf courses, grounds, lawns, sports fields. East Lansing: Michigan State University Press.

Snyder, R. L., L. J. Schwankl, D. A. Shaw, J. N. Kabashima, and M. A. Harivandi.1991. Turfgrass irrigation scheduling. Oakland: University of California Division of Agriculture and Natural Resources Publication 21499.

Schwankl, L. J., D. A. Shaw, M. A. Harivandi, and R. L. Snyder. 1992. Evaluating turfgrass sprinkler irrigation systems. Oakland: University of California Division of Agriculture and Natural Resources Publication 21503. 


\section{FOR FURTHER INFORMATION}

To order or obtain ANR publications and other products, visit the ANR Communication Services online catalog at http://anrcatalog.ucdavis.edu or phone 1-800-994-8849. You can also place orders by mail or FAX, or request a printed catalog of our products from

University of California

Agriculture and Natural Resources

Communication Services

6701 San Pablo Avenue, 2nd Floor

Oakland, California 94608-1239

Telephone 1-800-994-8849

(510) 642-2431

FAX (510) 643-5470

E-mail: danrcs@ucdavis.edu

(C)2009 The Regents of the University of California

Agriculture and Natural Resources

All rights reserved.

No part of this publication may be reproduced, stored in a retrieval system, or transmitted, in any form or by any means, electronic, mechanical, photocopying, recording, or otherwise, without the written permission of the publisher and the authors.

Publication 8395

ISBN-13: 978-60107-670-0

The University of California prohibits discrimination or harassment of any person on the basis of race, color, national origin, religion, sex, gender identity, pregnancy (including childbirth, and medical conditions related to pregnancy or childbirth), physical or mental disability, medical condition (cancer-related or genetic characteristics), ancestry, marital status, age, sexual orientation, citizenship, or service in the uniformed services (as defined by the Uniformed Services Employment and Reemployment Rights Act of 1994: service in the uniformed services includes membership, application for membership, performance of service, application for service, or obligation for service in the uniformed services) in any of its programs or activities.
University policy also prohibits reprisal or retaliation against any person in any of its programs or activities for making a complaint of discrimination or sexual harassment or for using or participating in the investigation or resolution process of any such complaint.

University policy is intended to be consistent with the provisions of applicable State and Federal laws.

Inquiries regarding the University's nondiscrimination policies may be directed to the Affirmative Action/Equal Opportunity Director, University of California, Agriculture and Natural Resources, 1111 Franklin Street, $6^{\text {th }}$ Floor, Oakland, CA 94607, (510) 987-0096.

For information about ordering this publication, telephone 1-800-994-8849. For assistance in downloading this publication, telephone 530-754-3927.

\section{UC}

REVIEWED This publication has been anonymously peer reviewed for technical accuracy by University of California scientists and other qualified professionals. This review process was managed by the ANR Associate Editor for Environmental Horticulture.

pr-8/09-SB/CR 